\title{
Analysis of Water Resources and Its Relation to Geological Structure in Arid and Semiarid Areas (Case Study: Plains of Kerman Province)
}

\author{
Dr. M.R.Nowjavan
}

Assistant Professor of Geomorphology, Islamic Azad University, Maybod Branch, Maybod, Iran

\section{Doi:10.5901/mjss.2015.v6n3s2p720}

\section{Abstract}

Iran is located on the world's belt of arid and semiarid climate and more than two-thirds of its area is experiencing dry conditions. The central zone of the country, and consequently the conditions of the plains of the province are tougher than the rest of the country, therefore in such circumstances, recognition of surface and ground water resources in the plains of Kermanbecomes highly important for sustainable resource management. The main purpose of this paper is to identify the interrelationships and complex geological formations and structures of plains of Kerman, using the pattern of surface and groundwaters for optimal management of this vital fluid in the study area. In this regard,first, allthe meteorological, hydrologic, hydrogeological, geological and the geographic information were collected and analyzed. Then, the geological, agrology, andhydrologic maps was drawn up in the Geographic Information System (GIS). Finally, the required digital layers extracted with base maps and digital elevation model (DEM) of the study area was overlapped. Also,thetechniques of remote sensing and image processing and analysis were used to identify geological structures. The results show that due to the changing nature of the dry plains of Kerman and calcareous material of the geological structure of the area,most of the water resourcesof the plains come from temporary surface water (flood) or ground water sources (wells, fountains, aqueducts. The greatest water resources are related to coarse alluvial deposits ofthe Quaternary period and alluvial fans that show an area with high potential. The results of this study can be used in the management of water resources and the plans for exploitation of these resources which is useful for achieving sustainable development.

Keywords: Water resources, surface water, Geographic Information System (GIS), Quaternary

\section{Introduction}

Iran is a dry and desert land with very low atmospheric precipitation in which the amount of rainfall is less than one third of the world level (Alizadeh, 2006). Therefore, due to the shortage of surface water resources, it is common to pump too much of ground water resources. More than 25 percent of the ground water resources of the country (65 out of 625) are in critical condition because of over-harvesting of the resources, and the number is increasing (Abbasspur and Anayi, 2001).

Kerman province is located in the subtropical high-pressure zone and far from the source of moisture; it has a low amount of rainfall. Variability and irregularity of rainfall is high, so that periodic droughts occur and negatively affect water resources of the province. Water resources of the provinceare divided into two categories: a) surface waters, b) groundwater

The water capacity of the provinceis 5.8 billion cubic meters, of which about 5.8 billion cubic meters surface and 4 billion cubic metersgroundwater areestimated.Currently, 4.6 billion cubic meters of these waters are being exploited of which 4 billion cubic meters are groundwater. With regard to the above issues, not all the plains of the province have significant surface and ground water, and most of water resources of the province depends on groundwater resources, and their exploitation is started and continues vehemently,as in the province for thewater years80-81 to 85-86the ground water level dropped an average of $90 \mathrm{~cm}$ (ShahiDashtandAbbasnejad, 2011).Pumping more than the limit from the water tables of the province had negative outcomes such as changing of the quality of the ground water, forwarding of the sour water passion, reduction of the water resources volume, change in hydrodynamic coefficients of water tables, compulsory increase of the wells depth, drying resources of harvesting water (wells, springs, aqueducts), increasing energy consumption,underground harvesting, increasing vulnerability rate of the plains against droughts, subsiding of earth, creation of seam and gap in earth and buildings, damage to thefacilities, endangering of the natural ecosystem, drying of farms and gardens. The main purpose of this paper is to identify the direction of surface water and groundwater and their compliance with the geological structure of Kerman plain to manage these valuable resources. Valuable researches were done on the plains of Iran and its water resources, some of which include:Saif and Kargar(2011) Plain of 
Sirjan, Abbasnejad (1998) plain of Rafsanjan, Ebrahimiet al (1999) Plain of Zarand, Abbasnejad (2004) EkhtiyarAbadof Kerman, Shahidokht(2008),Kerman,Rafsanjan,Jiroft and Zarand.

\section{Materials and Methods}

In this study, using the library -documentary method, initially numerous references, books and articles were collected, after the collection and classification of relevant sources, the next step was to provide statistical information.Based on this, by visiting the sites and the organizations various measures,we prepared climate data, meteorological data of shallow groundwater, wells and aqueducts, and the harvesting of any one of them. Then we tried to enter data and to providemain database of Geographic Information System (GIS). In this regard, the provision of digital layers such as a layer of surface water hydrology, geology layer, and agrology layer was attempted and thematic maps were plotted for each of them. Finally, the overall operations of the various layers were used to analyze the relationship between each layer and the geological structure of the area. Obviously, the use of satellite imagery helped the researchers in the analysis.

\section{Thelocation of Study Area}

Kerman province is in southeastern Iran, and between $53^{\circ}$ and 26 minutes up to $59^{\circ}$ and 29 minutes Length East, and Between $25^{\circ}$ And 55 minutes To $32^{\circ}$ Width North.

The province has over 181.785 square kilometers total of 11 percent of the country`s area, which ranked first in terms of area in the country. From the North, it neighbors with the provinces South Khorasanand Yazd;from the south, it neighbors with the province of Hormozgan; from the east,it neighbors with the province ofSistan and Baluchistan;from the westit neighbors with the province of Fars. According to the latest divisions until the end of 2010, the province has 23 cities, 64 towns, 58 sections, and 151 rural districts.

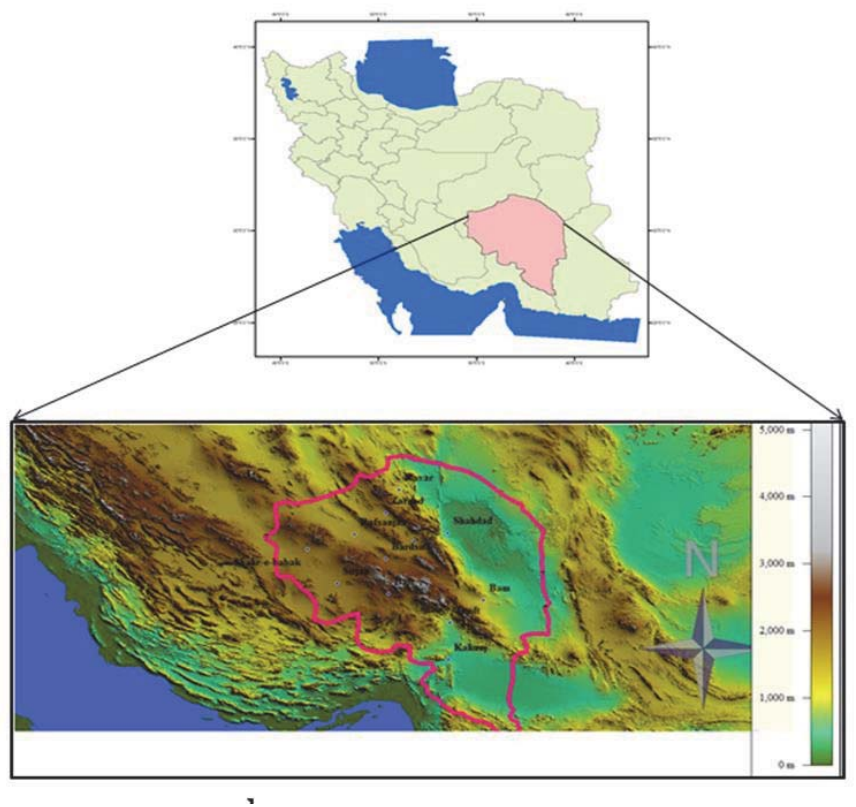

Figure 1. The location of study area

\section{Geological Features of the Study Area}

Iran's Kerman province is in South East, having various shapes form the morphological point of view. Eastern regions of the province are limited to very large desert zones, which continue to Sistan and Baluchestan. Its central regions 
are mountainous (high) and the most important mountains are Barez Mountains. In south western parts,Kerman is neighboring the Zagros Mountains.

From the perspective of large-scale geographic structure, Kerman province hashigh structural diversity. In the South West part of the structural zone Zagros and crushed zone and the southern part of the structural zone includes the Makran. Sanandaj (West region of Sirjan zone B to close the prison at Kahnuj rocks and mountains in the province of UrmiaDokhtar volcanic belt along a northwest to southeast from the pomegranate close to the southeast, it extends the bass in a.

Paleozoic platform of the East and North and North East Central covered much of the province. Large stone statues in the province can be divided into the following categories:

1. Sedimentary platform which includes Paleozoic Mesozoic sediments statues, including areas of Zarand, Kohbanan, Kerman ,Mahan and Ravar.

2. Igneous intrusions platform ofTertiary and Quaternary periods, and outputs that are part of a larger magmatic mamedUromia-Dokhtar. The belt of volcanic rocks of alkaline-phosphatase and granitoid intrusions of different ages, which are mainly related to the Tertiary and Quaternary .

3. Metamorphic Paleozoic era statues in a northwest trending belt east of town B C Knob continues to Manoj and has covered a wide range in the South West province .

4. Paleozoic and Mesozoic ophiolite suites of mafic and Avltrmafyk statues and early Tertiary in the areas of DolatabadHajiabadEsfandaqehKahnuj and Babak and tissue development and ophiolite complexes in the geology of the color mixtures are known ophiolite.

5. Zagros sedimentary statues, statues, mostly plains and foothills and desert Quaternary sediments comprise mostly comprises the alluvial sediments. During his life in this province of the Cambrian geological structure has been EXTREMELY Olfactory and now the outlook is very active ground motion.

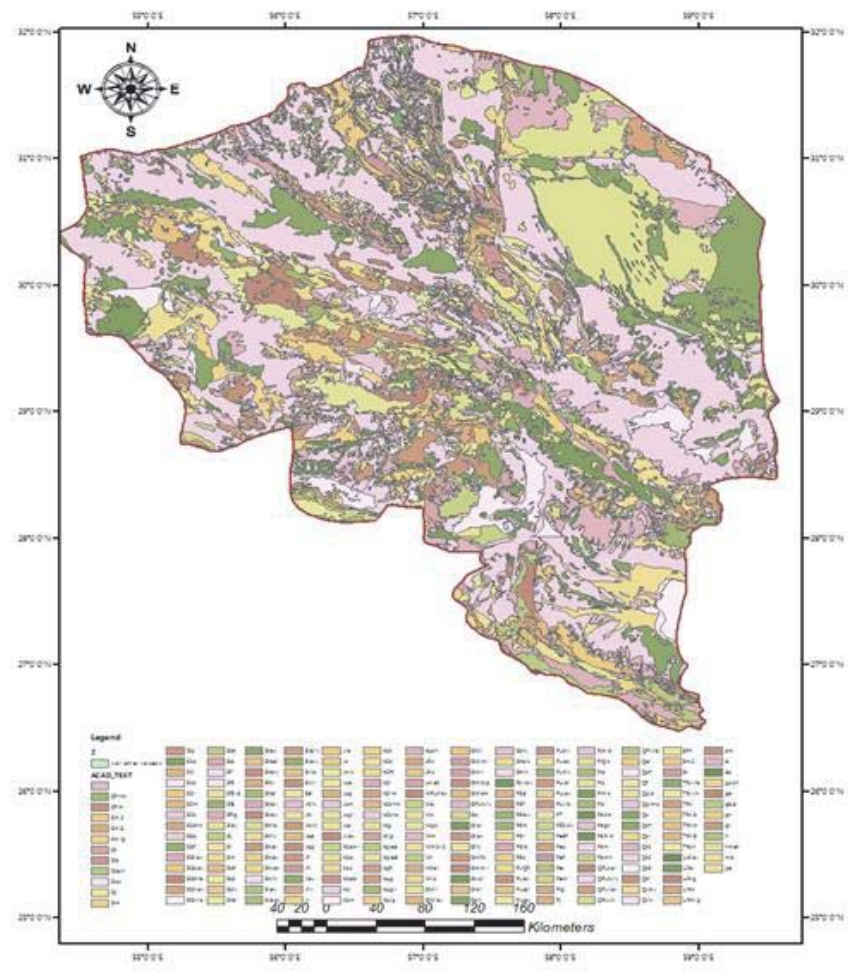

Figure 2. Geological formations comprising the plains of the province 


\section{Surface Water Hydrology and Its Relationship with the Geological Structure of the Area}

Plains province Consist of Enteric Continual, Seasonal And the By chance are That Factor Flood Seismicity Upper Have.

In Table 1. The name of the 28 rivers and their watershed and source is given.

Table 1. Surface water resources plains of the province

\begin{tabular}{|l|l|l|}
\hline River & Basins Bryzasly & Source \\
\hline HalilRud - Jiroft & Western Jazmoryan & Shah Heights \\
\hline Passion - Jiroft & Western Jazmoryan & Sarduieh Heights - Dlfard \\
\hline Agheyn - Jiroft & Western Jazmoryan & Mountain Heights obvious \\
\hline Nisa - BAM & Lut & Mountain Heights obvious \\
\hline Aduri, Faryab - BAM & Lut & Mountain Heights obvious \\
\hline Derakhtangan - Char Farsang & Lut & Heights Foothills \\
\hline Shirin - Ravar & Lut & Pabdana Heights \\
\hline Soorakhe Mar - Rhine & Lut & North Highlands Sarduieh \\
\hline G-hvyyh - Rhine & Lut & South Hazar \\
\hline Tanguiyeh - Sirjan & Salt desert Sirjan & Chhargnbd Heights \\
\hline Gyvdry - Rafsanjan & Central Desert & Red Mountain House \\
\hline Haft Kusk & Central Desert & Hazaran \\
\hline Charlie - Arab village & Central Desert & Hazaran \\
\hline Water Bkhsha' - Bardsir & Central Desert & Shah Heights \\
\hline Pomegranate & Desert Bafg & Mount Msahym \\
\hline Jowzam (Chavrchy) - Shahr & Plain pomegranate & Mhmdabadv heights of ShahrBydsvkhth \\
\hline Ravar & Lut & Pabdana Heights \\
\hline Ryan Lamb Svz- & Lut & South Heights Hazar \\
\hline Shvr- Rafsanjan & Desert Bafg & Source heights \\
\hline From Qatruyeh area - Ravar & Lut & Hvtkn Heights \\
\hline Dhbkry- bass & Lut & DehBekr Heights \\
\hline Myths - Sirjan & Percussion muzzle blood & Mount cynic \\
\hline Saidi & Central Desert & Ten Yary- Heights Foothills \\
\hline Hossein Abad Sirjan & Percussion muzzle blood & South Heights Chhargnbd \\
\hline Polymetallic - Shahr & Heart and Marvast & Highlands North East Shahr \\
\hline Tajv- Shahrbabak & Heart and Marvast & Highlands North East Shahr \\
\hline Squinch-Kerman & Central Desert & Polvar Heights \\
\hline Rubber-textured-Soltani (branches Rud) & Jazmoryan & North Highlands city of \\
\hline & & \\
\hline
\end{tabular}

However, due to geological structures and the surface area, it must be checked that most of surface water streams flow on which formations, in order to prepare the digital tier of surface water, (Figure 3) geological map of the level of stream The overlap of data (Figure 4), thereby passing the highest level of the heads on the low-lying plains, alluvial fans, terraces valley was (Qft2) . The density of the population is clear waterways. This means that most of the Plains aquifer province on alluvial fans, pediment, the terraces and Quaternary sediments are located, the use of these resources and their management in these areas would be more logical and more efficient ( See Figure 4). 


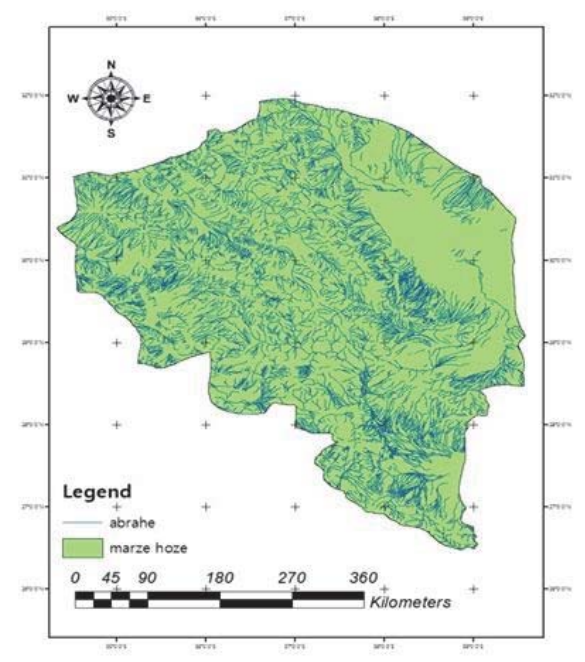

Figure 3. Map of Kerman province Plains Hydrology (layer Yrahh s)

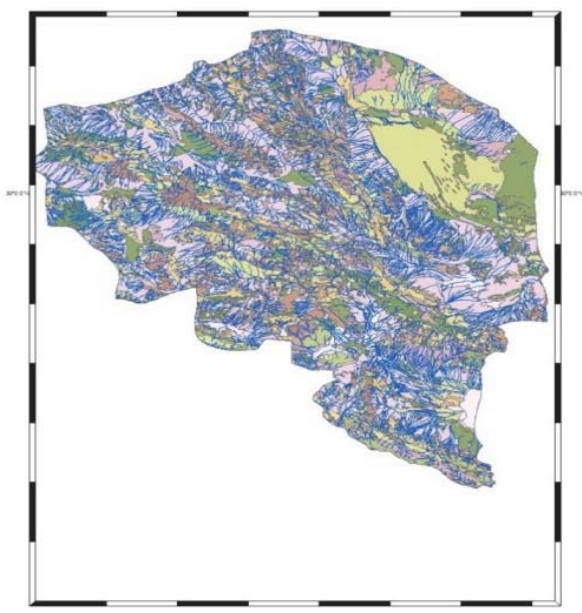

Figure 4 - Surface water layer overlaps with the geological structure of the area

\section{Kerman Groundwater Resources and How to Harvest Them}

Travels of water can be released into groundwater aquifers and groundwater pressure divided trips. Free water in the aquifer, the aquifer is located on impermeable rocks and sediments of the rock is impermeable to water in the saturated zone is called the saturated zone above the water table is located. Plain By Province Kerman Most of the Type Table By The after free to there.tablecloths By free location shape of fountain and, drilling aqueducand the drilling well and the setup turbine By rinse are.province kerman In the living room present With 32248 Point Discharge The water Ground water Discharge General Equivalent 6.746 Billion M In the Year Is (Company Shares Thewater Area Kerman 1999). Plain Roudbar With the To have 7600 Source Discharge The water, The Count Resources Blue To In the Between Plain The Province There. The Of the It Plain The Elite, Manoj, Castle Treasure, Faryab Klashgrd And theRafsanjan Between 1500 Up to 3,000 Source Blue There. The Removal In the Single Level, In the Plain The Elite, Nowdezh, Tissue, Bardsir, Bam And the Narmashir And the Manoj Form and There.To the Way $90.38 \%$ of the total Discharge The water Ground In the Province Kerman Through Well and 5.98 percent By the Aqueduct And And 3.64 percent By spring And Form and Be. With the Attention To the That Economy Area On Basic activities The Agriculture Firm Is 96.86 percentOf 
the The water Extracted resources Ground In the Section Agriculture, drinking water and 0.8 per cent to 3.34 per cent In the Industry Consumption and The Average Guidance Electrical Wells The Province Around 2860 micromhos On Cm The M respectively. The water GroundA dash The Svghan, Sarduieh, Dhk.han, Tissue, Soltani, Rubber And the Bezenjan, Best Quality And the The water Well Plain The Ravar,SERIES - Tghraljrd, Kerman, Rafsanjan, Zarand and the Sirjan, Worst Quality To Dara . On Basis Studies Performance By, Salinity Thewater Some Areas Province Such as Margin Western Plain Sirjan, Noogh And the Pomegranate In the Rafsanjan SERIES, To the Some The above Is That Problems Serious To Residents The Areas Create And the Even Plants And the Beasts To The In the To Risk Serious TheData (The king and Abbasnejad, 2010).

\section{Drop Table Plains Province}

Total Addition Removal Of the Table The Province In the Year 86 blue, 85 more than One Billion Meter Cubic Estimate By Is That Plain RafsanjanIn the The Year With the Addition Perception Equivalent to 220.5 million M The Share Have Is (Figure 5).

During the One 6-year period (81-80,86-85) Plain Rafsanjan With the Reduction V Equivalent to 970 million M, the maximum Reduction VolumeTank To Inthe Between Plain The Province Have Is Reduction Volume Tank Plain The Kahnuj, Government Abad, Sirjan Andthe ShahrbabakMore Of the Other Plain And Been A. The lowest The Reduction Volume Tank The In the Plain The Shahdad, Ravar And the Mercy Abad EventWorked (Figure 6). Status Plain The Important Province The During the The Period To the Cheek The It was the That 5.4\% of Zarand plain aquifers, 4.54 percent Of the Volume Table Plain Rafsanjan, 5.05\% of the Volume Table Plain Sirjan, 4.4\% Of the Volume Table Jiroft in Kerman desert plain end table is reduced from 7.7 (Abbasnejad King, 2010). For example, under the zoning map Location Level The water Ground Map drop ( $\mathrm{m}$ ) is a plain Kerman in 1385 (Fig. 7 and 8).

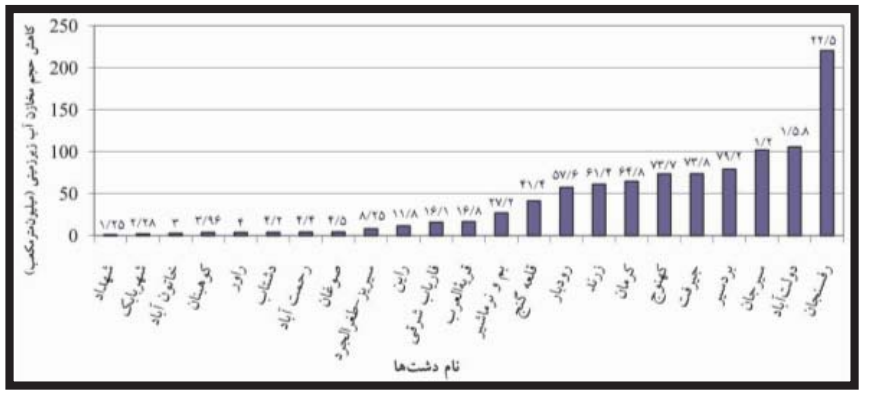

Figure 5. The Addition Removal In the Each Of the Dash Tasks Province In the Year 86 Blue 85 (Penny Plain, Abbasnejad 2011)

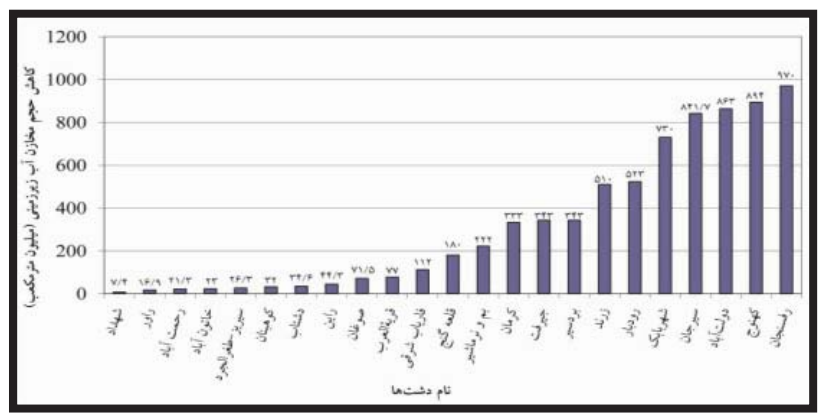

Figure 6. The Reduction Volume Zkhayraby Plain The Province During the Year Hay81-80 and 86-85 (King Plains, Abbasnejad 2011) 


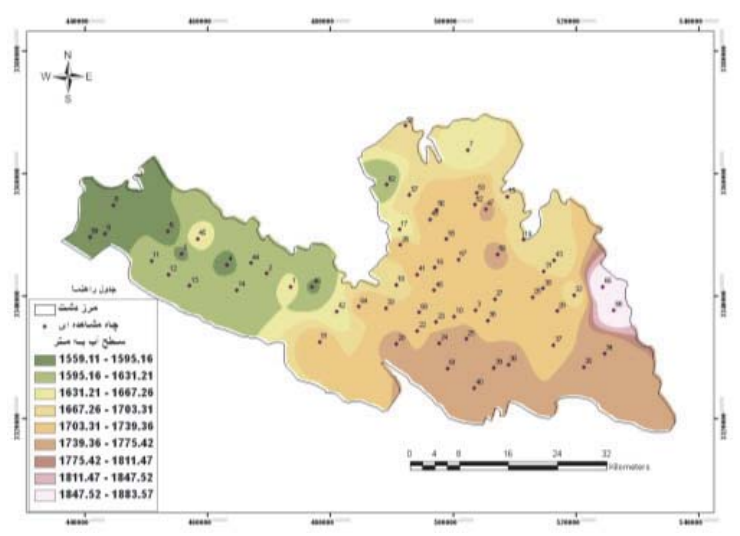

Figure 7- Zone Classification Location Level The water Groundwater ( M) Plain Kerman In the 2006 (Mohammadi et al., 2012)

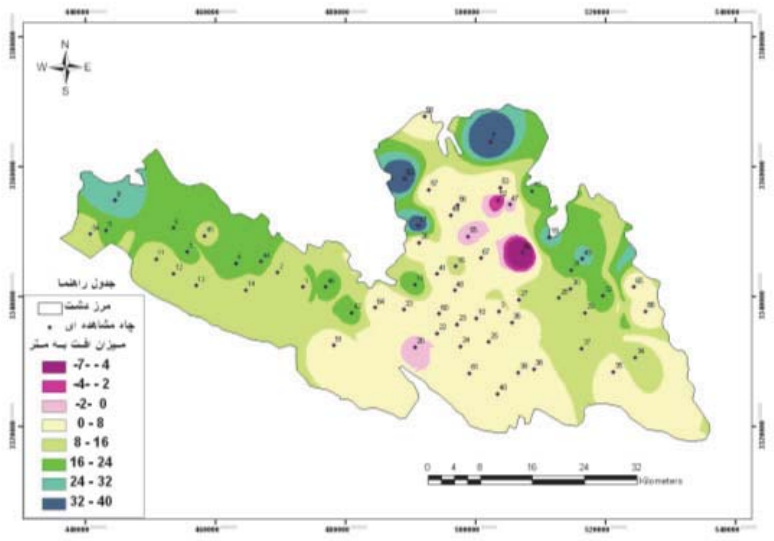

Figure 8. Map of the drop (m) groundwater Kerman (Mohammadi et al., 2012)

\section{Conclusion}

Kerman province tectonic structural variation is high. In the South West part of the structural zone Agres and crushed zone and the southernpart of the structural zone includes the Makran. Sanandaj (West region of Sirjan zone B to close the prison at Kahnuj rocks and mountains in the province of Urmia girl volcanic belt along a northwest to southeast from the pomegranate close to the southeast, it extends the bass. Of The structure of this region resulted in the emergence of massive and high Grabny- Hurst (Hurst) on the one hand and the creation of vast plains and craters (graben) is the other. Such geological structure is the overall image of ripples and watersheds in the region has drawn on this basis about 28 major rivers, temporary and seasonal flow in this region is closely related to the geological conditions of the region.

The results show that due to the variable nature of the dry plains of Kerman and sex limestone geological structure of the area's major water resources plains or through temporary surface water (flood) or through ground water sources (wells, fountains, aqueducts) are provided.The greatest water reserves in accordance with coarse alluvial deposits of the Quaternary (Quaternary) and alluvial fans that show an area with high potential. The lowest water potential Mrbrt limited to northern and western highlands because of steep studies and the water is low maintenance. Another area of water power is consistent with the geological structure of the earth is flat and low slope Rsy- marl and gypsum due to the very low permeability and high evaporation Is. 


\section{References}

Abbas Poor, The ., Favors, F ., 2001, " Crisis The Environment Environmental And he Program Planning Development Sustainable In the Iran " , Collection Articles First Conference National Critical Final $(G)$ the environmental policy Iran And the Approaches Recovery That,University Free Islamic Single Sciences Research Ahvaz, 2015-202.

Alizadeh, Th, 2006, "Principles Hydrology Applied " University Press Imam Foster, 808 Page.

Abbas Race, The . , 2004 , " Cavity Subsides Karst In the Available Abad -North West West Kerman " , Journal Scientific Research SciencesEarth, No. 52-51, 35-28.

Abbas Race, or., 1998, "Survey Conditions And the Issues Environment Environment Plain Rafsanjan "pressed Articles The secondConference Community The earth Iran, Tehran, Mashhad, 310-303.

Cress Plain, S.R., 2008, "Evaluation Effects Environment Environmental Removal Without Procedures Of the Table The water Ground Province Kerman and the Offering Approaches Reliable The letter MA Geological Environmental, Along With the Applications SoftUniversity of Arc GIS software Shahid Bahonar Kerman, 294 pages.

Penny Plain, A., A. Race, A., 2011 " Offering The Guidelines Management Resources The water Ground Plain The Province Kerman, Journal of Applied Geology, Vol. VII, 131-146.

Cress Plain, S. R., Abbas Race, L., 2011 "Management Resources Blue Challenge and the Reading strategies Case Province Kerman "Fourth, Iran, Congress International Geographers The world Islam, 2010, (ICIWG). 